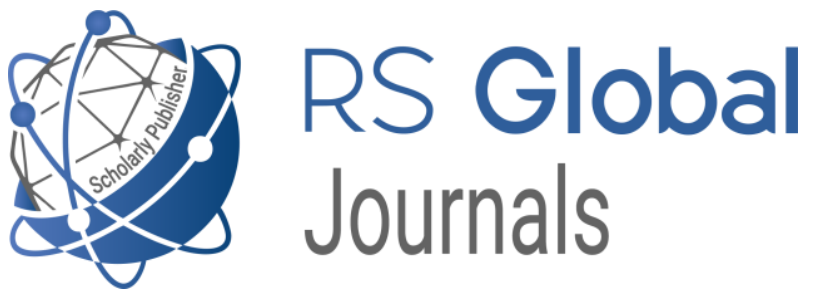

Scholarly Publisher

RS Global Sp. z O.O.

ISNI: 0000000484952390

Dolna 17, Warsaw, Poland 00-773

Tel: +48226022703

Email: editorial_office@rsglobal.pl

JOURNAL International Journal of Innovative Technologies in Social Science

p-ISSN

2544-9338

e-ISSN

2544-9435

PUBLISHER

RS Global Sp. z O.O., Poland

ARTICLE TITLE

ПСИХОЛІНГВІСТИЧНИЙ АСПЕКТ КОМПЛЕКСНОЇ МЕДИКО-ПСИХОЛОГІЧНОЇ ДОПОМОГИ ДІТЯМ В УМОВАХ ТУРБУЛЕНТНОГО ЧАСУ

$\operatorname{AUTHOR}(\mathbf{S})$

Кабанцева Анастасія Валеріївна

Kabantseva Anastasiia. (2021) Psycholinguistic Aspect of Complex Medical-Psychological Assistance to Children in

ARTICLE INFO Turbulent Conditions. International Journal of Innovative Technologies in Social Science. 2(30). doi: 10.31435/rsglobal_ijitss/30062021/7569

DOI https://doi.org/10.31435/rsglobal_ijitss/30062021/7569

RECEIVED

29 April 2021

ACCEPTED

03 June 2021

PUBLISHED

07 June 2021

LICENSE

This work is licensed under a Creative Commons Attribution

4.0 International License.

(C) The author(s) 2021. This publication is an open access article. 


\title{
ПСИХОЛІНГВІСТИЧНИЙ АСПЕКТ КОМПЛЕКСНОЇ МЕДИКО-ПСИХОЛОГІЧНӦ̈ ДОПОМОГИ ДІТЯМ В УМОВАХ ТУРБУЛЕНТНОГО ЧАСУ
}

\author{
Кабанцева Анастасія Валеріївна, \\ кандидат психологічних наук, дочент кафедри психіатрії, психотерапї, наркологї і медичної \\ психології Донецького національного медичного університету МОЗ України, Україна, \\ ORCID ID: https://orcid.org/0000-0001-7678-6052
}

DOI: https://doi.org/10.31435/rsglobal_ijitss/30062021/7569

\section{ARTICLE INFO}

Received 29 April 2021

Accepted 03 June 2021

Published 07 June 2021

\section{KEYWORDS}

emotions, mental activity, war, armed conflict, eastern Ukraine, comprehensive medical and psychological care.

\begin{abstract}
Modern turbulent conditions, characterized by social, economic, political crises, information, and psychological pressure put under risk the child's psyche, its psycho-emotional sphere, thinking, and speaking. Purpose: based on the results of the study of the psycho-emotional state of children living in socially stressful conditions, to identify current problems of their development and hypothetically determine the importance of psycholinguistics in the development of technology for comprehensive care for the latter. Main results: Fears of various nature were found among $61.2 \%$ of children; feelings of loneliness present among $57.4 \%$ of children, anxiety among $53.2 \%$ of children, manifestations of aggression among $36.7 \%$. Children with fear of war $(51.5 \%)$ note that war is scary; war is when people are killed, when adults and children cry, when shots are fired, houses, kindergartens, and schools are destroyed. Discussion: implementation of psycholinguistic research in medical and psychological care will identify the child's psycho-emotional state by the features of the voice, assessment of semantic constructions, which will contribute to more accurate differentiation of psychological and physical condition, planning tactics of care will assess the effectiveness of corrective measures and treatment. Conclusions: socially tense situation develops an anxious premonition, the constant expectation of something bad by both children and adults. The psycholinguistic aspect of complex medical and psychological care is presented in the development of a set of techniques and operational principles (conceptual approaches), which will be the basis for modeling effective strategies of thinking and behaving in turbulent conditions.
\end{abstract}

Citation: Kabantseva Anastasiia. (2021) Psycholinguistic Aspect of Complex Medical-Psychological Assistance to Children in Turbulent Conditions. International Journal of Innovative Technologies in Social Science. 2(30). doi: 10.31435/rsglobal_ijitss/30062021/7569

Copyright: (C) 2021 Kabantseva Anastasiia. This is an open-access article distributed under the terms of the Creative Commons Attribution License (CC BY). The use, distribution or reproduction in other forums is permitted, provided the original author(s) or licensor are credited and that the original publication in this journal is cited, in accordance with accepted academic practice. No use, distribution or reproduction is permitted which does not comply with these terms.

Вступ. Турбулентний час в яке вступило людство представлено динамізмом змін, складністю i неоднозначністю інформаційного середовища, а також невизначеністю, непередбачуваністю, нестабільністю політичної та соціальної діяльності в країні, розвитком економічних криз і різноманітних воєн (збройна, інформаційна, проксі-війни), що породжують синергетичний ефект та обумовлює об'єктивний характер виникнення ризикованих чинників, які ускладнюють процес адаптації до змін, що відбуваються (Панченко, 2020). Подібні явища змінюють емоційне реагування людини, іiі розумові конструкти, мовні звороти, лексичний запас, трансформуючи психологічну інтерпретацію слова. Це носить масштабний характер і впливає на всіх членів суспільства, в тому числі, і на дітей. Останні стають «заручниками» своїх травматичних переживань, їм складно до кінця зрозуміти свої почуття, хвилювання, переживання і дійсність того, що відбувається в цілому. 
Таким чином, надання допомоги постраждалим дітям повинна бути комплексною, що включає психологічну, педагогічну, медичну та соціальну складові. Психологічний супровід має полягати не тільки в, як такій, підтримці дитини та їі сім'ї, а мати активний характер впливу, що представлено психолінгвістичним аспектом. Саме психолінгвістика виступає тим фахівцем, який акумулює в єдине ціле мислення, мову і людську свідомість, що особливо актуально в епоху турбулентного часу, так як сьогодні світова спільнота, виходячи з сукупності глобальних процесів, призводить до нестабільності світову систему думки.

Теоретико-методологічний аналіз показує, що в області психолінгвістики зроблені суттєві дослідження у вивченні мови дітей, надання спеціалізованої допомоги при затримці психомовного розвитку і розробки багатьох інших питань. Досить повно вивчені проблеми корекції комунікації при соціальних (прагматичних) комунікативних розладах, функціональних розладах аутистичного спектру (Adams, C. \& Gaile, J., 2020), стан розвитку мотивів мови і операцій лексико-граматичного структурування дитячих висловлювань (Kalmykova, L., Volzhentseva, I., Kharchenko, N., \& Mysan, I., 2019), особливості соціокультурних передумов вульгаризації мови дітей (Mezhov, O., Navalna, M., \& Kostusiak, N., 2020), техніки розвитку мовної активності (Волженцева, I. 2017, Suprun, D., \& Fedorenko, M., 2019), але сучасні виклики турбулентного часу ставлять нові завдання для наукової спільноти, зокрема в попередженні виникнення психічної патології серед дітей з нормотиповим розвитком.

Знання про актуальний психоемоційний стан дітей, виявлення переважних у них психоемоційних проблем будуть сприяти розробці методології та організації психолінгвістичних досліджень в роботі з категорією, які зазнали психологічного насильства. Тим самим, подібне сформує розуміння значущості психолінгвістики в комплексній медикопсихологічної допомоги, яка до цих пір майже не розглядалася в науковому співтоваристві, i не має повноцінної практичної реалізації.

Мета роботи: на основі результатів дослідження психоемоційного стану дітей, які проживають в соціально-напружених умовах, встановити актуальні проблеми їх розвитку i гіпотетично визначити значимість психолінгвістики в розробці технології надання комплексної допомоги останнім.

Методи і методики дослідження. Роботу виконано в рамках науково-дослідної теми за запитом Міністерства охорони здоров'я України «Розробка технології медико-психологічної реабілітації та соціальної абілітації дітей, які отримали психологічне насильство» (номер державної реєстрації - 0120U101301). У період ведення збройного конфлікту на сході України на базі дУ «Науково-практичний медичний реабілітаційно-діагностичний центр МО3 України» проводились дослідження психоемоційного стану дітей Донецької області у віці 5-7 років. Загальна кількість респондентів - 1308 дітей. Використовувалися теоретико-методологічні, емпіричні та статистичні методи дослідження. Проведено психосемантичний аналіз. Психодіагностичний комплекс склали психологічні методики: «Неіснуюча тварина» (М.3. Друкаревіч), «Кактус» (М.А. Панфілова), опитувальник страхів А.І.Захарова, тест «Драбина» (В. Щур), «Малюнок сім'ї» (Г.Т. Хоментаускас). Застосування сукупності представлених методів дозволили встановити домінуючі страхи, емоційні переживання, рівень самооцінки, актуальний внутрішньосімейний клімат; розробити пропозиції взаємодії вузькопрофільних фахівців в системі «дитина-дорослий» $\mathrm{i}$ встановити психолінгвістичний аспект комплексної медико-психологічної допомоги.

Результати дослідження. За результатами проведеного психологічного дослідження у $61,2 \%$ дітей, які взяли участь, були виявлені страхи різного характеру; наявність тривожності $53,2 \%$; прояви агресивності - 36,7\%.

Встановлено, що для більшої половини респондентів характерними є страх фізичного збитку і страх війни (табл.1). При розмові з дітьми про страхи виявлено, що розуміння війни у них представлено не як про дитячу гру, де все відбувається віртуально, а як реальна загроза для них та їхніх близьких (мами, тато, братів, сестер, дідуся, бабусі та інших). У дітей зі страхом війни (51,5\%) зафіксовані такі коментарі в ході бесіди як: війна - це страшно; війна - це коли вбивають людей, коли плачуть дорослі і діти, коли відбуваються постріли, руйнуються будинки, дитячі садки, школи. Цим дітям не подобаються іграшки, які в тій чи іншій мірі пов'язані з війною (пістолети, автомати, ножі, мечі, рації і ін.). Вони насторожено ставляться до різких звуків. У цих дітей сформовано «доросле» уявлення про війну - реальна загроза для життя і здоров'я людей. 
Високі показники діагностовано серед соціальних, медичних, просторових, страхів тварин і темряви. Соціальні, медичні, просторові страхи і страх темряви є умовною нормою для дітей дошкільного віку (Кабанцева \& Корнєєва, 2018), чого не можна сказати про страхи фізичного збитку і страх війни, які є набутими і вони не характерні для даної вікової категорії (табл.1).

Таблиця 1. Наявність страхів у дітей, які проживають на сході України

\begin{tabular}{|l|c|c|}
\hline \multicolumn{1}{|c|}{ Види страхів } & Кількість респондентів & $\%$ \\
\hline Страх фізичного збитку & 704 & 53,8 \\
\hline Страх війни & 644 & 51,5 \\
\hline Медичні страхи & 575 & 45,1 \\
\hline Соціальні страхи & 564 & 45,1 \\
\hline Страхи темряви & 577 & 46,2 \\
\hline Страх тварин & 442 & 35,4 \\
\hline Страх відкритого простору & 361 & 31,3 \\
\hline
\end{tabular}

У 57,4\% дітей встановлено відчуття самотності, незахищеності в своїх сім'ях. Поряд із цим, при дослідженні дитячо-батьківських відносин встановлено, що сприятливу сімейну атмосферу мали 966 осіб, несприятливу внутрішньосімейну ситуацію - 342 осіб, що склало 27\% (рис. 1).

Статистично доведено, що чим більше проявів агресії з боку дорослих, тим вище рівень проявів власної агресивності у дітей $(\mathrm{r}=0,302 ; \mathrm{p} \leq 0,01)$, тим частіше вони не відчувають себе частиною своєї сім'ї $(\mathrm{r}=0,435 ; \mathrm{p} \leq 0,05)$. Нехтування батьком породжує у дітей потребу в додаткової уваги $(\mathrm{r}=0,305 ; \mathrm{p} \leq 0,01)$, а нехтування матір'ю викликає розвиток тривожності $(\mathrm{r}=0,422 ; \mathrm{p} \leq 0,01)$ і невротичних станів $(\mathrm{r}=0,431 ; \mathrm{p} \leq 0,01)$.

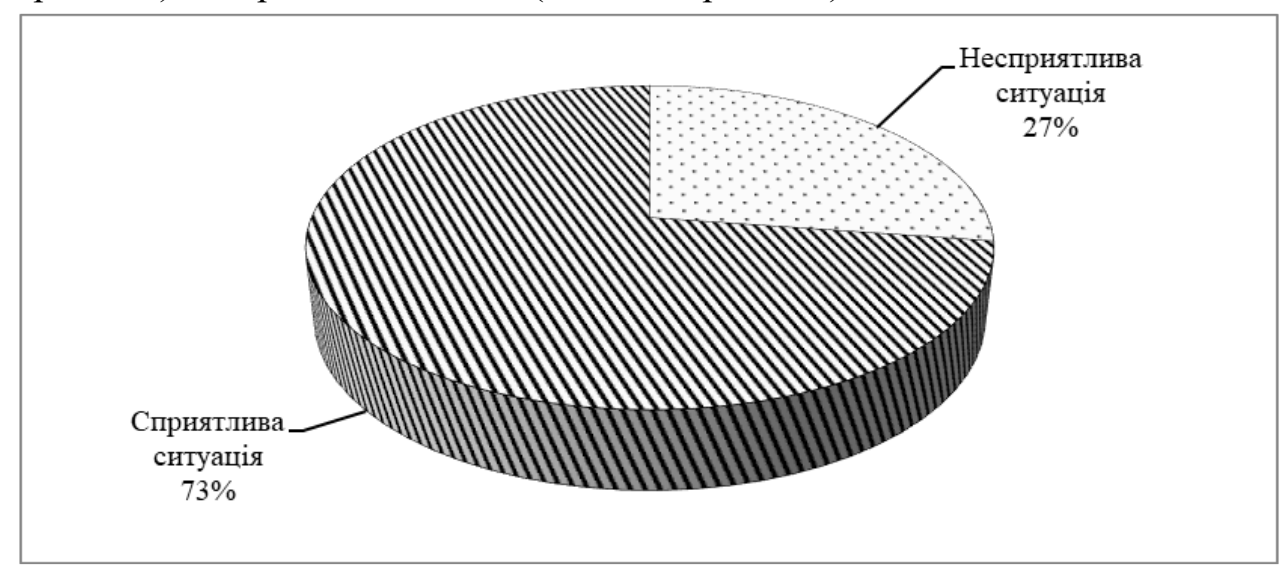

Рис. 1. Внутрішньосімейна атмосфера респондентів

Отже, навіть при сприятливому сімейному кліматі дитина може не відчувати того рівня безпеки і комфорту, яких вимагає ії індивідуально-психологічний або психоемоційний стан, що впливає і на ії самоццінку.

Обговорення результатів. Для дитини перших років життя (дошкільний період) сім'я відіграє провідну роль. Особливо цей факт набуває значення при несприятливих соціальних умовах, таких як: нагнітання соціальної нестабільності в суспільстві через інформаційні атаки засобів масової інформації, проведення антитерористичної операції і об'єднаної операції збройних сил на території держави, фізичні, моральні, матеріальні втрати як наслідки останніх. На виникнення емоцій дітей $\mathrm{i}$, тим більше, в бойових умовах, великий вплив має інтелектуальна й інформаційна переробка батьків щодо пережитих подій, які відбуваються в навколишньому середовищі, їх відображення через мовні конструкції, семантичні одиниці, мовні звороти. Переважання в мові таких слів як війна, вибухи, зброя, обман, що супроводжуються відповідною емоційністю, проявом страху, хвилюванням, тривогою формують негативне інформаційно-психологічне поле в якому знаходяться їхні власні діти.

Із огляду на вікові особливості, діти не завжди можуть правильно описати свій актуальний стан, зазначити які переважають емоції, почуття, описати справжні причини 
переживань. Прояви носять стертий характер, поступово примножуючи симптоми, які $\epsilon$ незавершеними і до кінця невизначеними. Фобії, страхи, істеричні фантазії, спонтанна тривожність і тривожне передчуття - все це теж сфера підсвідомості. Готовність індивіда діяти в різних ситуаціях певним чином, без попереднього обдумування, імпульсивно також відноситься до проявів підсвідомої сфери психіки.

Проведення психолінгвістичних досліджень в роботі з дітьми має науково-прикладний аспект, зокрема, щодо оцінки психологічного благополуччя та клінічної динаміки пограничних психічних розладів. Тим самим підвищуючи ефективність діагностики, лікування, реабілітації та профілактичних заходів. На малюнку 2 представлений психолінгвістичний аспект основних етапів надання допомоги.

Допомога дітям безперечно повинна носити комплексний медико-психологічний характер, $\mathrm{i}$ якщо розглядати більш детально, то пропонується розширення уявлень етапів допомоги, а саме: діагностичний, оціночно-планований, лікувально-корекційний, підсумково-рекомендаційний, рекреаційно-профілактичний етапи. Організація процесу полягає в наданні допомоги дітям та їх батькам, як головним суб'єктам процесу цілковитого і багатостороннього розвитку. У даній системі комплексної допомоги впровадження психолінгвістичних досліджень на діагностичному етапі роботи $з$ дітьми реалізує завдання ідентифікації психоемоційного стану дитини за особливостями ії голосу (висота, тембр, ритм, плавність тону), оцінка семантичних конструкцій (вивчення зв'язку слів і людської реальності, переважаючої групи слів, визначення поєднання слова 3 іншими словами, залежне значення слова від контексту фрази). За результатами цих досліджень буде відбуватися більш точна диференціація психологічного і фізичного стану, планування тактики надання допомоги. Так як буде можливість конкретизувати переважаючий стан, зокрема наявність порушення або гальмування (пасивність). У першому випадку, переважає хвилювання, нервозність, непосидючість, а по-другому - втома, безініціативність, байдужість, апатія. У бесіді тембр голосу може вказувати на відношення до того чи іншого явища, ситуації; відчуває, дитина печаль, горе, роздратування, огиду, страх або спокій, веселощі, радість.

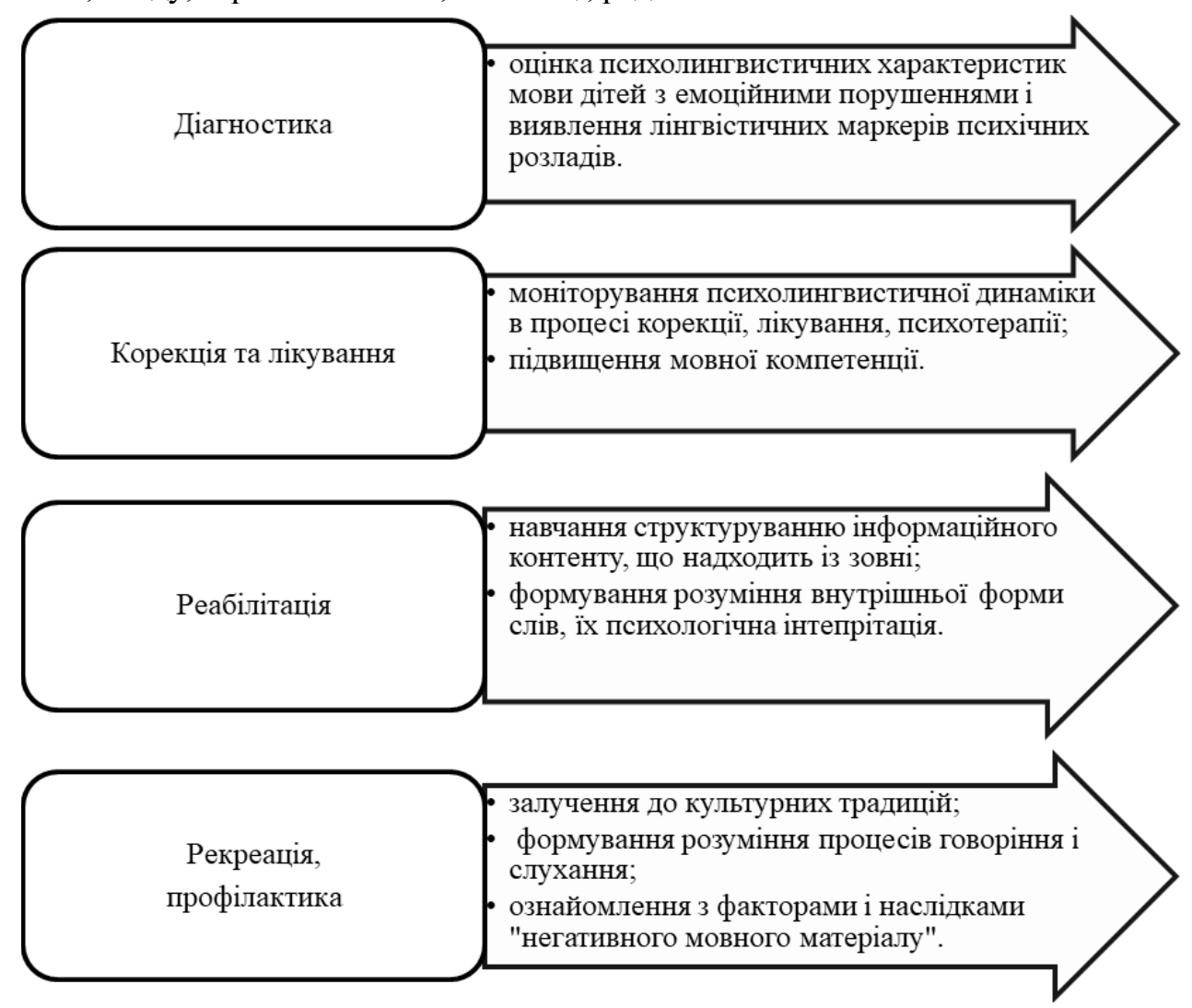

Рис. 2. Психолінгвістичний аспект комплексної медико-психологічної допомоги дітям

Проведення подібних досліджень в період відновлення дозволить оцінювати ефективність розроблених корекційних заходів і хід самого лікування, тому корекційні i профілактичні програми повинні включати реалізацію технології «інжиніринг психіки 
людини», що грунтується на виявленні і використанні стандартів мислення, вироблення внутрішніх механізмів самовладання. При цьому керуючи внутрішнім духовним світом i формуючи усвідомлення явищ мовної дійсності. Подібне стане можливим при навчанні розумінню власних думок, почуттів, емоцій; усвідомленості особистих потреб, бажань і вмінню їх трансформувати в мовні знакові одиниці. Формування практичних мовних навичок і облік сучасних соціальних інтеграцій вдосконалять комунікативні форми взаємодії, побудови адекватної «Я-концепції» і нормальних відносин в системі «Я - інші».

Таким чином, застосування психолінгвістичного підходу сприятиме високому рівню діагностики і розробці максимально точного маршруту корекції, лікування і реабілітації дитини.

Висновки. 1. Результати емпіричних досліджень показують, що наслідки громадянського конфлікту, соціально-економічної нестабільності, інформаційно-психологічного тиску несуть негативний вплив на психоемоційний стан дітей. Більше 50\% дітей сходу України мають страх війни, що представлені «дорослим» уявленням про неї. Вони відчувають небезпеку військового характеру, фізичного збитку і реальну загрозу для життя і здоров'я.

2. Розвиток дитини має бути багатогранним, не тільки спрямованим на інтелектуальну складову, а на всі сфери (емоційно-вольову, мотиваційну, комунікативно-мовленнєву, фізичну, соціальну, саморегулюючу, сенсорну, духовну). Але психологічному благополуччю i сприятливому розвитку дітей перешкоджають наявні страхи різного походження (полігамність страхів - 61,2\%, з них страх війни - 51,5\%), прояви тривожності $(53,2 \%)$, агресивності $(36,7 \%)$, несприятливий внутрішньосімейний клімат (27,3\%).

3. Несприятлива сімейна атмосфера формує у дітей почуття самотності та незахищеності, що в свою чергу впливає на самооцінку, сприйняття себе і своїх можливостей. Наслідками, встановлених проблем стає невміння впоратися з емоційними переживаннями, що тягнуть за собою зміну розумових процесів, комунікації, погіршення психологічного комфорту, соматичного здоров'я та розвитку психопатології.

4. Соціально-напружена обстановка розвиває тривожне передчуття, постійне очікування чогось поганого як у дітей, так і у дорослих. Тому, психолінгвістичний аспект комплексної медико-психологічної допомоги показує свою високу значимість, а саме в розробці комплексу технік і операційних принципів (концептуальних підходів), які стануть основою моделювання ефективних стратегій мислення і поведінки людини в умовах турбулентного часу.

\section{ЛІТЕРАТУРА}

1. Волженцева, И. Развитие эмоционально-выразительной стороны речи дошкольника средствами онтопсихологической музыкотерапии. Психолінгвістика. Психолингвистика. Psycholinguistics. 2017. Вип. 22 (1). С. 26-42.

2. Кабанцева, А., Корнеева, О. Підтримка дитини в умовах емоційного напруження: навчальнометодичний посібник. К.: КВІЦ, 2018, 136 с.

3. Калмикова, Л.О. Мовленнєва діяльність як складова предмета психолінгвістики. East European Journal of Psycholinguistics. 2015. 2(1). 59-67.

4. Кособукова, О.В. Развитие представлений о смысле и личностном смысле в отечественной психологии. Вестник КГПУ им. В.П. Астафьева. 2009 (1). URL: https://cyberleninka.ru/article/n/razvitie-predstavleniy-osmysle-i-lichnostnom-smysle-v-otechestvennoy-psihologii.

5. Панченко, О. Информационно-психологическая безопасность в эпоху турбулентности: монография. К.: КВИЦ. 2020. 472 с.

6. Adams, C., Gaile, J. Evaluation of a parent preference-based outcome measure after intensive communication intervention for children with social (pragmatic) communication disorder and highfunctioning autism spectrum disorder. Research in Developmental Disabilities. 2020. 10. URL: https://doi.org/10.1016/j.ridd.2020.103752.

7. Kalmykova, L., Volzhentseva, I., Kharchenko, N., \& Mysan, I. Без мотива не бывает целенаправленной речевой активности: своеобразие детских монологических высказываний. Psycholinguistics. 2019. 25(1), 107-146. https://doi.org/10.31470/2309-1797-2019-25-1-107-146

8. Mezhov, O., Navalna, M., \& Kostusiak, N. Invective Vocabulary in Media Discourse at the Beginning of the 21st Century: A Psycholinguistic Aspect. East European Journal of Psycholinguistics. 2020. 7(1). URL: https://doi.org/10.29038/eejpl.2020.7.1.mez.

9. Suprun, D., \& Fedorenko, M. Психолингводидактика развития речевой активности у детей старшего дошкольного возраста с аутистическими нарушениями. Psycholinguistics. 2019. 25(1), 281-299. https://doi.org/10.31470/2309-1797-2019-25-1-281-299. 